\title{
Gradient Chromatofocusing-Mass Spectrometry: A New Technique in Protein Analysis
}

\author{
Lian Shan,* James A. Hribar, Xiang Zhou, and David J. Anderson \\ Department of Chemistry, Cleveland State University, Cleveland, Ohio, USA
}

\begin{abstract}
A new analytical technique, gradient chromatofocusing-mass spectrometry (gCF-MS), was developed employing ion-exchange high-performance liquid chromatography (HPLC) interfaced to an electrospray-quadrupole mass spectrometer in the determination of proteins. There have been few reports, if any, of a HPLC-MS technique for proteins in which the ion-exchange column is directly interfaced to the mass spectrometer. The employment of a linear $\mathrm{pH}$ gradient elution scheme directly interfaced to mass spectrometry is also unique in the present work. The technique was demonstrated by the separation of six proteins (carbonic anhydrase II, enolase, $\beta$-lactoglobulin $\mathrm{A}$, lactoglobulin $\mathrm{B}$, soybean trypsin inhibitor, and amyloglucosidase) employing a descending linear $\mathrm{pH}$ gradient from $\mathrm{pH} 9$ to 2.6 on a $50 \mathrm{~mm} \times 2.1 \mathrm{~mm}$ DEAE HPLC column using volatile buffer components. A signal enhancement solution consisting of $8 \%$ formic acid in acetonitrile was pumped post-column and was mixed 1:1 with column effluent and then directed on-line into the mass spectrometer. Molecular masses of the proteins were determined within $\pm 0.010 \%$ to $0.033 \%$ ( \pm 100 to $330 \mathrm{ppm}$ ) with peak height total ion current detection limits of 4 to $78 \mathrm{pmol}$ of injected amounts $(\mathrm{S} / \mathrm{N}=3)$. This technique is applicable to the analysis of proteins and other charged molecules. (J Am Soc Mass Spectrom $2008,19,1132-1137$ ) (C) 2008 American Society for Mass Spectrometry
\end{abstract}

$\mathrm{T}$ There is great interest in developing a mass spectrometry (MS)-compatible high-performance liquid chromatography (HPLC) technology which performs charge-based separations, a principal dimension in the 2D-gel electrophoresis technique, for application in proteomic and protein characterization studies. Development of such a HPLC technique would be progress towards addressing the limitations of the 2D-gel electrophoresis technique, which has been hampered by its design incompatibility for direct interfacing with MS (requiring excision of each protein band from the gel), limitation in quantitative dynamic range, inability of determining small proteins (5-8000 Da), high labor intensity, long sample run times, as well as other disadvantages $[1,2]$.

Development of charged-based HPLC techniques directly coupled to mass spectrometry (MS) has been a difficult challenge. This is because the mobile phase salts commonly used in ion-exchange chromatography, the most used charge-based HPLC technique, suppress the MS signal. The most utilized approach incorporating ion-exchange chromatography with mass spectrometry has been to use a 2D ion-exchange/reversed-phase HPLC technique, directing the ion-exchange fractions to a reversed-phase column for further separation and removal of salt before on-line mass spectrometry. This

Address reprint requests to Dr. D. J. Anderson, Department of Chemistry, Cleveland State University, 2121 Euclid Avenue, Cleveland, Ohio 441152214, USA. E-mail: d.anderson@csuohio.edu

* Present address: Frantz BioMarkers LLC, 7740 Metric Drive, Mentor, Ohio 44060, USA. has been applied to proteomic studies in the analysis of proteins [3] and protein digests [4,5]. A "stair step" gradient is employed for the ion-exchange dimension. This first dimension thus serves as a crude initial separation step, and is not the stage that is directly interfaced to the mass spectrometer.

The application of two-dimensional chromatography using the combination of chromatofocusing and reversed-phase HPLC has also been reported [6-8]. In this application, chromatofocusing is employed as an off-line fractionation step. The fractions collected at 0.2 or $0.3 \mathrm{pH}$ units are then applied to a reversed-phase HPLC, from which the eluent is directed into a mass spectrometer for analysis. However, in these studies, chromatofocusing is still used as a low resolution, first stage separation step.

Capillary isoelectric focusing has also been interfaced to an electrospray-mass spectrometer for protein and peptide analysis. It has been successfully employed in the characterization of the proteome of $E$. Coli with the detection of 400 to 1000 proteins [9, 10]. This technique requires the use of low concentrations, which compromises peak width, or complete removal of the carrier ampholytes with a microdialysis setup, to obtain an on-line MS signal [11, 12]. Problems with this technique are protein adsorption to the capillary walls, which lead to reproducibility problems [13] and the effect of protein concentration on the $\mathrm{pH}$ gradient [14].

A few reports have been published using volatile displacer ions/acids in the mobile phase, such as ammonium acetate/acetic acid or ammonium formate/ 
formic acid, for ion-exchange chromatography techniques directly interfaced to an electrospray mass spectrometer in the analysis of drugs $[15,16]$, chlormequat [17], nucleoside triphosphates [18], and peptides [19]. However, these reports have not led to widespread use of ion-exchange chromatography interfaced to MS because the volatile ions have relatively weak displacing power [20,21]. This necessitates the use of high concentrations of displacer ions in the mobile phase that not only suppress the MS signal but also limits the applications to smaller, more readily displaced analyte molecules. Higher concentration of displacer eluents are required for large molecules, such as proteins, due to the large molecule's multiple sites of interaction with chromatographic packing materials [22].

The present work demonstrates the direct interfacing of a high-resolution ion-exchange technique, gradient chromatofocusing [23-26], to MS employing electrospray ionization (ESI). This technique, gradient chromatofocusing-mass spectrometry (gCF-MS), is a general approach for interfacing ion-exchange chromatography to mass spectrometry, drawing upon a $\mathrm{pH}$ elution mechanism through employment of a linear $\mathrm{pH}$ gradient using volatile buffer components. This differs from the displacement mechanism of the usually employed salt gradients, and has better compatibility with MS through the use of volatile buffer species (such as lactic acid, acetic acid, ammonium bicarbonate and pyridine) and lower buffer concentrations. This allows ionexchange MS to be applied to different types of ionic analytes. If the principal mechanism of elution of proteins is displacement, then high buffer concentrations are needed, which precludes on-line MS detection. However, high concentration buffers are not required in the $\mathrm{pH}$-based gCF-MS technique, which permits protein analysis. The use of a $\mathrm{pH}$ gradient in this technique is also advantageous over salt gradient ion-exchange techniques in that the $\mathrm{pH}$ elution mechanism is a better indicator of the $\mathrm{pI}$ value of the protein. The present work employs the gCF-MS technique for the separation of proteins and the direct determination of their molecular mass.

\section{Experimental}

\section{Proteins}

Carbonic anhydrase II (CA II) from bovine erythrocytes (C-3640) $(0.089 \mu \mathrm{g} / \mu \mathrm{L})$, enolase from baker's yeast (E-6126) $(0.22 \mu \mathrm{g} / \mu \mathrm{L}), \beta$-lactoglobulin A and B $(\beta$-LA and $\beta$-LB) from bovine milk (L-7880 and L-8005, respectively) $(0.18 \mu \mathrm{g} / \mu \mathrm{L}$ and $0.089 \mu \mathrm{g} / \mu \mathrm{L}$, respectively), trypsin inhibitor (TI) from Glycine max (T-9003) (0.244 $\mu \mathrm{g} / \mu \mathrm{L}$ ), and amyloglucosidase (AG) from Aspergillus niger (A-7420) $(0.311 \mu \mathrm{g} / \mu \mathrm{L})$ were obtained from Sigma (St. Louis, MO) and were made up with water to the concentrations given in the parentheses.

\section{Instrumental Design}

The instrumental design for gradient chromatofocusing interfaced via ESI to a quadrupole mass spectrometer is given in Figure 1.

\section{Chromatography Conditions}

The aqueous application Buffer A consisted of $25 \mathrm{mM}$ ammonium bicarbonate and $25 \mathrm{mM}$ pyridine adjusted to $\mathrm{pH} 9$ with concentrated ammonium hydroxide. The aqueous elution Buffer B consisted of $25 \mathrm{mM}$ acetic acid and $25 \mathrm{mM}$ lactic acid (no $\mathrm{pH}$ adjustment, measured $\mathrm{pH}$ of 2.6). The buffer components were either ACS reagent or HPLC grades. An increasing gradient of Buffer B mixed with Buffer A was generated and pumped at 0.2 $\mathrm{mL} / \mathrm{min}$ through a $50 \mathrm{~mm} \times 2.1 \mathrm{~mm}$ HPLC column packed with Protein-Pak DEAE 8HR (8 $\mu$ m diameter, $1000 \AA$ pore size) weak anion-exchange packing material from Waters (Milford, MA) at $6.9 \times 10^{6} \mathrm{~Pa}$ using a HPLC packer from Alltech (Deerfield, IL). The program used to generate the outlet $\mathrm{pH}$ gradient ( $\mathrm{pH} 9.0$ to 2.6) plotted in Figure 2 was: $38 \%$ B for $4 \mathrm{~min}, 38 \%$ to $41 \%$ B linear gradient for $10 \mathrm{~min}, 41 \%$ to $51 \%$ B linear gradient for $4 \mathrm{~min}, 51 \%$ to $61 \%$ B linear gradient for $10 \mathrm{~min}, 61 \%$ to $95 \%$ B linear gradient for $14 \mathrm{~min}$, and $95 \%$ to $100 \%$ B linear gradient for $8 \mathrm{~min}$. A $10 \mathrm{uL}$ sample (protein amounts given in Table 1) was injected. The $\mathrm{pH}$ gradient was determined from a blank run, without injection of sample, by collection and $\mathrm{pH}$ measurement of $0.4 \mathrm{~mL}$ fractions collected after the UV detector.

\section{Mass Spectrometry Conditions and Data Analysis}

Column effluent was mixed on-line 1:1 with $8 \%$ formic acid in acetonitrile, which enhanced the total ion current (TIC) mass spectrometric signal. The parameters for the mass spectrometer were as follows: detection mode was positive; source temperature was $90^{\circ} \mathrm{C}$; scanning of quadrupole was 800 to $2500 \mathrm{~m} / \mathrm{z}$ in $3.5 \mathrm{~s}$; cone voltage was ramped linearly from 40 to $90 \mathrm{~V}$ during the scan; capillary voltage was $3.5 \mathrm{kV}$; nitrogen nebulizer gas had a flow rate of $12 \mathrm{~L} / \mathrm{h}$; nitrogen drying gas had a flow rate of $300 \mathrm{~L} / \mathrm{h}$. Before the run, the mass spectrometer was calibrated by infusion experiments. This was done by following the procedure given by the manufacturer, using a mixture of sodium iodide (2 $\mathrm{mg} / \mathrm{mL})$ and cesium iodide $(0.05 \mathrm{mg} / \mathrm{mL})$ in $50: 50$ isopropanol and water.

Data were analyzed by MassLynx ver. 3.3 from Waters. Chromatograms were processed as follows: no background subtract; half-width of the smoothing window, \pm 3 scans; number of smooths, 2; smoothing method, mean. For generating the mass spectra, continuum data scans were combined over the half-height portion of the peak. MaxEnt parameters were set at default values: uniform Gaussian algorithm at a widthat-half-height, $0.750 \mathrm{Da}$; mass range, 5000 to $100,000 \mathrm{Da}$; 


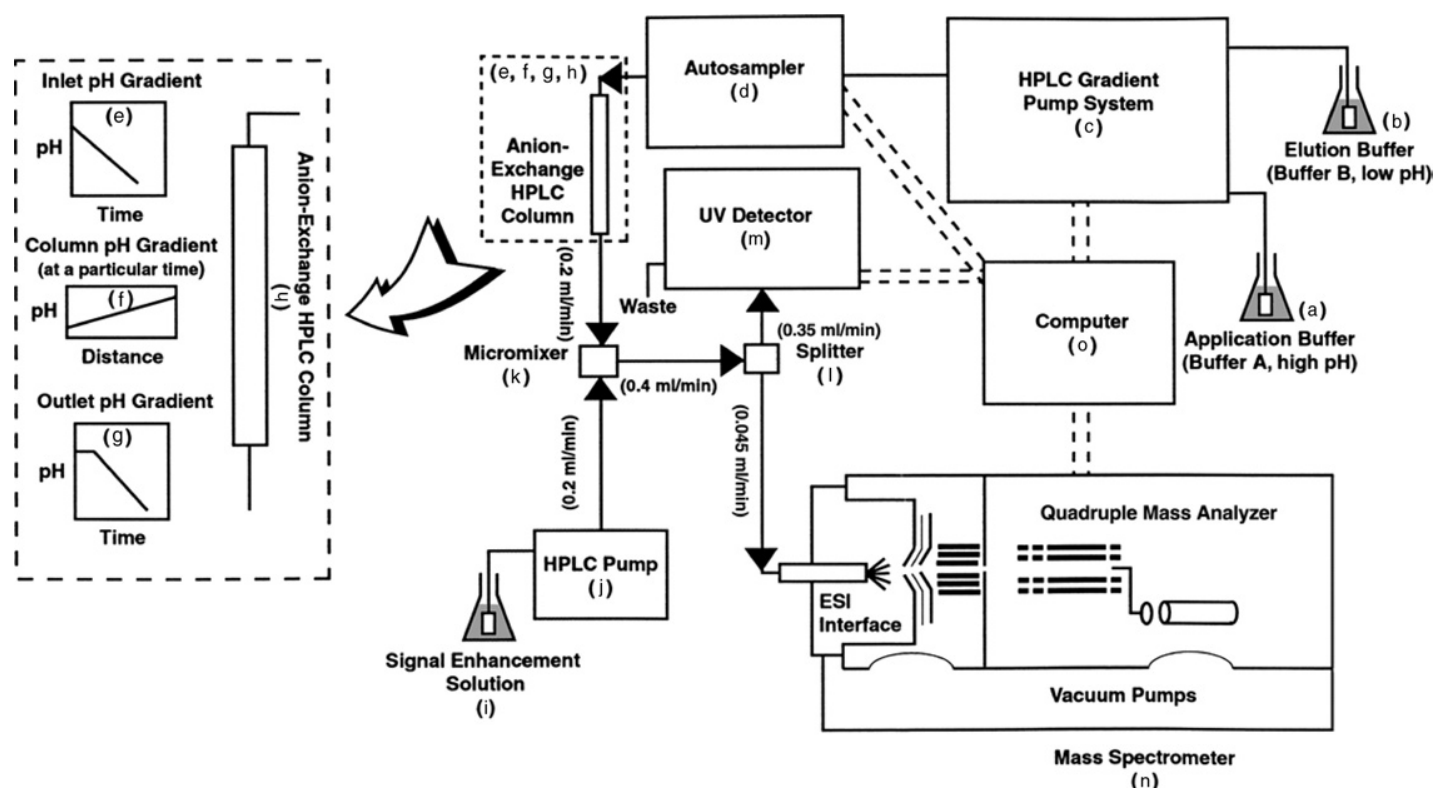

(n)

Figure 1. Gradient chromatofocusing-mass spectrometry system. (a) Aqueous application Buffer A and (b) aqueous elution Buffer B are mixed and pumped at $0.2 \mathrm{~mL} / \mathrm{min}$ by (c) a HP $1100 \mathrm{HPLC}$ gradient system from Agilent (Palo Alto, CA) to form (e) an inlet $\mathrm{pH}$ gradient. When the inlet $\mathrm{pH}$ gradient is introduced onto $(\mathbf{h})$ a weak anion-exchange HPLC column produces (f) a column $\mathrm{pH}$ gradient, which is important to focusing the peaks, and (g) an outlet $\mathrm{pH}$ gradient, which causes separation of the peaks [23, 24]. Sample is injected by (d) a HP 1100 Autosampler from Agilent. (i) Signal enhancement solution consisting of $8 \%$ formic acid in acetonitrile is pumped by $(j)$ a $\mathrm{LC}-\mathrm{AD}_{\mathrm{VP}}$ HPLC pump from Shimadzu (Columbia, MD) at $0.2 \mathrm{~mL} / \mathrm{min}$ and mixed with the column effluent in (k) a $10 \mu \mathrm{L}$ Visco-Jet Micro-Mixer from Lee Company (Westbrook, CT). The flow after the micro-mixer was split 1 to 7.9 with (1) a splitter, directing $355 \mu \mathrm{L} / \mathrm{min}$ to (m) a HP $1100 \mathrm{UV}$ detector from Agilent set to $280 \mathrm{~nm}$ and $45 \mu \mathrm{L} / \mathrm{min}$ through an ESI source into (n) a Micromass Quattro II electrospray ionization-triple quadrupole mass spectrometer from Waters (Milford, MA) operated in the single quadrupole mode. (o) A Compaq Professional Workstation AP200 computer from Hewlett-Packard (Palo Alto, CA) computer controlled the HPLC, autosampler, MS, and UV detector, as well as being used for the collection and analysis of data.

resolution, $1.0 \mathrm{Da} /$ channel; minimum intensity channels, 33\% for both left and right.

\section{Results and Discussion}

Six proteins were separated and analyzed by gradient chromatofocusing directly interfaced to a quadrupole mass spectrometer with the total ion current (TIC) chromatogram given in Figure 2. The $\mathrm{pH}$ gradient was generated with volatile buffer components that are compatible with mass spectrometry.

\section{Mass Spectrometry Aspects}

The mass spectra for the protein peaks were generated, both the scanning $\mathrm{m} / \mathrm{z}$ and the deconvoluted spectra. Example scanning $\mathrm{m} / \mathrm{z}$ and deconvoluted spectra are given in Figure 3 for $\beta$-lactoglobulin B. Experimentally determined detection limits are summarized in Table 1. Experimental molecular masses matched theoretical values within \pm 0.010 to $0.033 \%$ ( \pm 100 to $330 \mathrm{ppm}$ ), which is within the reported accuracy of quadrupole techniques $(0.01 \%$ to $0.04 \%)$ [1]. All protein peaks gave scanning $\mathrm{m} / \mathrm{z}$ spectra that could be deconvoluted to determine correct molecular masses. The exception was amyloglucosidase. The reasons for this are discussed below. No adducts were noted in the deconvoluted spectra, even in runs in which formic acid was not present in the signal enhancement solution.

The detection limits of the technique for the $50 \mathrm{~mm} \times$ $2.1 \mathrm{~mm}$ column were at the pmol level. It ranged from 4 to 78 pmol, using the data given in Table 1 and a criterion of a signal-to-noise $(\mathrm{S} / \mathrm{N})$ for the TIC chromatogram peak height equal to three. Coefficients of variation for duplicate runs of the five proteins given in Table 1 (all except amyloglucosidase, which did not yield a discernable scanning $\mathrm{m} / \mathrm{z}$ spectrum) using the mass chromatogram peaks (summing the signal from the specific $\mathrm{m} / \mathrm{z}$ signals for each protein) averaged $0.6 \%$ (range $0 \%$ to $1.4 \%$ ) and $9.4 \%$ (range $3.4 \%$ to $15.2 \%$ ) for the retention times and peak areas, respectively. There was no significant loss of performance after more than $48 \mathrm{~h}$ of continuous operation.

Proteins with subunit components $(\beta$-lactoglobulin A, $\beta$-lactoglobulin B, and enolase) were determined as their subunit molecular masses. The technique demonstrated the ability to differentiate protein isoforms coeluting within one peak, with two forms of trypsin 


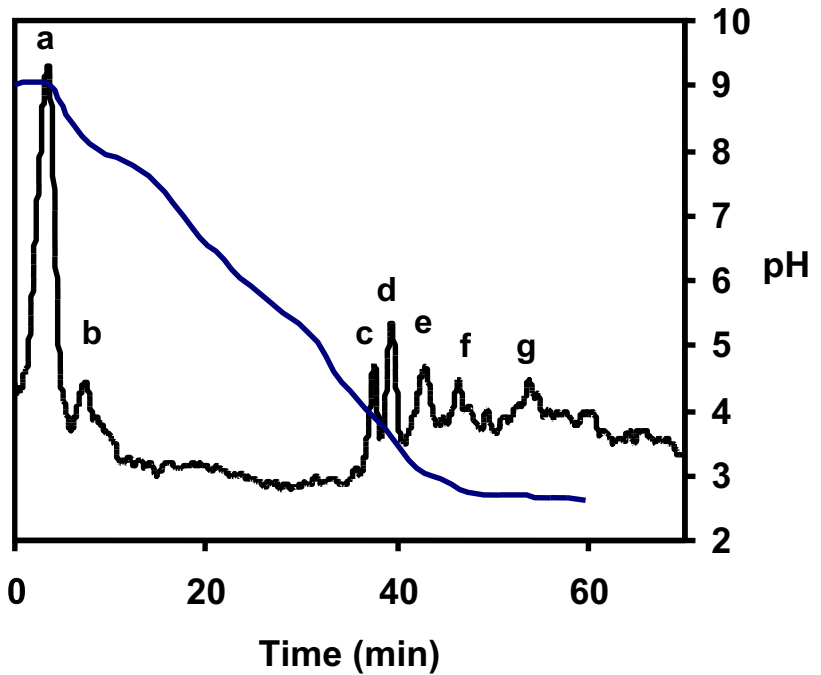

Figure 2. The TIC chromatogram of the protein mixture (amounts given in Table 1) on a DEAE HPLC column with the $\mathrm{pH}$ gradient plotted. The peaks are (a) carbonic anhydrase II; (b) enolase; (c) $\beta$-lactoglobulin B; (d) $\beta$-lactoglobulin A; (e) soybean trypsin inhibitor; (f) amyloglucosidase (G2 form); and (g) amyloglucosidase (G1 form).

inhibitor identified in peak e of Figure 2, having measured molecular masses of 20,086 and 19,973. These peaks correspond to intact trypsin inhibitor and a fragment of trypsin inhibitor missing the C-terminus leucine (deduced from the mass difference), respectively. This capability of differentiating multiple coeluting components, as well as the accurate determination of molecular mass, are important advantages of MS detection over UV.

There was no discernable scanning mass spectrum and only a weak TIC signal for amyloglucosidase, even with a tenfold increase in injection amount over the amount given in Table 1. Negative mode detection was also tried and did not yield a discernable mass spectrum. The low MS signal for this protein may be due to

Table 1. Total ion chromatography results

\begin{tabular}{|c|c|c|c|c|c|}
\hline \multirow[b]{2}{*}{ Protein } & \multicolumn{2}{|c|}{$\begin{array}{c}\text { Total ion } \\
\text { current }\end{array}$} & \multirow[b]{2}{*}{$\mathrm{pl}$} & \multirow[b]{2}{*}{$\begin{array}{c}\text { Elution } \\
\mathrm{pH}\end{array}$} & \multirow[b]{2}{*}{$\begin{array}{c}\text { Pk wt Hf- } \mathrm{Ht} \\
\text { (pH unit) }\end{array}$} \\
\hline & $\begin{array}{l}\text { Inj amt } \\
\text { (pmol) }\end{array}$ & $\begin{array}{l}\mathrm{Pk} \mathrm{ht} \\
\mathrm{S} / \mathrm{N}\end{array}$ & & & \\
\hline CA II & 31 & 21 & $5.4^{\mathrm{a}}$ & 9.03 & b \\
\hline Enolase & 24 & 3.9 & 6.1 [27] & 8.35 & 0.25 \\
\hline$\beta$-LB & 24 & 5.7 & 5.23 [28] & 4.72 & 0.23 \\
\hline$\beta$-LA & 49 & 7.5 & $5.13[28]$ & 4.40 & 0.16 \\
\hline TI & 122 & 4.7 & $4.61^{c}$ & 3.87 & 0.18 \\
\hline \multirow[t]{2}{*}{$A G$} & 38 & d & & 3.36 & 0.21 \\
\hline & & & $3.50[29]$ & 2.84 & b \\
\hline
\end{tabular}

${ }^{\text {a } F r o m ~ m a n u f a c t u r e r ' s ~ t e c h n i c a l ~ i n f o r m a t i o n . ~}$

bNot calculated since protein partially eluted in the plateau region of the $\mathrm{pH}$ gradient.

${ }^{\mathrm{C}}$ Calculated by PeptideMass program of the Expert Protein Analysis System (ExPASy) of the Swiss Institute of Bioinformatics (http://us. expasy.org).

${ }^{\mathrm{d} N o t}$ given because percentage of different isoforms not known.
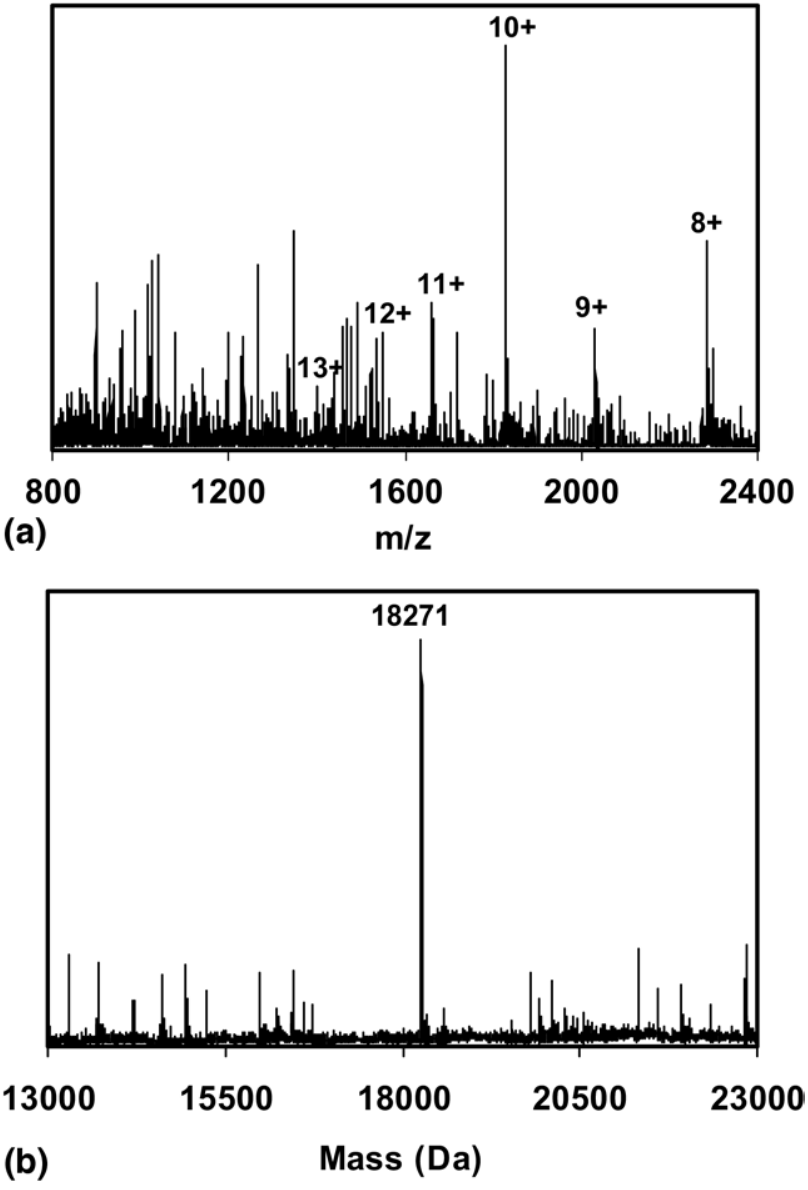

Figure 3. (a) Scanning and (b) deconvoluted mass spectra of the $\beta$-lactoglobulin B peak in Figure 2. Largest signal is $1.8 \mathrm{e}^{5} \mathrm{cps}$ and $3.5 \mathrm{e}^{5}$ cps for scanning and deconvoluted spectra, respectively. Scans were accumulated over the half-height portion of the peak. MaxEnt 1 from Waters was used to generate the deconvoluted mass spectra. Data manipulation parameters are given in the Experimental section.

one or more factors. It could be due to its high carbohydrate content $(20 \%$ to $23 \%$ by weight [30] which is known to suppress electrospray response [31, 32]. In addition, loss of the specific scanning MS signal can occur in highly glycosylated proteins due to heterogeneity in the glycoprotein carbohydrate structure, which can either come from a fundamental heterogeneity in the native glycoprotein molecules or arise from heterogeneous fragmentation of carbohydrate group(s) in the ionization process [33]. From previous anion-exchange chromatography work [30] peaks $f$ and $g$ in Figure 2 are tentatively assigned as the G2 and G1 isoforms of amyloglucosidase, respectively.

\section{Post-Column Signal Enhancement Solution}

A signal enhancement solution was pumped postcolumn and mixed with the column effluent to augment the detection of proteins. This signal enhancement solution consisted of an organic component, acetonitrile, and a weak acid component, formic acid. The 
acetonitrile promotes optimal spraying that is critical to the ESI process. It does this by lowering the surface tension of the mobile phase to produce a stable spray [32]. In addition, the organic component may augment the MS signal by promoting more efficient desolvation of the analyte in the ESI process due to an increase in the percentage of the more volatile solvent [32]. The formic acid component of the signal enhancement solution promotes positive charging of the protein through its acid characteristics [32].

In general, the optimal composition of the signal enhancement solution was found to be $8 \%$ formic acid in $75 \%$ to $100 \%$ acetonitrile in water for the various proteins, increasing the TIC signal by a factor of 6 to 18 for most of the proteins (for carbonic anhydrase II there was no TIC peak noted without the signal enhancement solution). It should be noted, however, that the optimum acetonitrile concentration determined in this study is dependent on instrumental parameters [32]. Thus, the optimum organic content needs to be determined for the specific mass spectrometer system and parameters used.

Another consideration for determining the optimum formic acid concentration is noise. It was noted that TIC noise level increased by a factor of 1.6 to 4.4 in different regions of the chromatogram when a signal enhancement solution of $8 \%$ formic acid in acetonitrile was used compared to the noise level when acetonitrile without formic acid was used. However, the protein $\mathrm{S} / \mathrm{N}$ did improve by a factor of 2 to 3 for the $8 \%$ formic acid in acetonitrile compared with that of acetonitrile alone. It is possible, however, that further gains in $\mathrm{S} / \mathrm{N}$ may be realized at lower formic acid concentrations, in which signal enhancement is maintained but noise level is reduced.

\section{Chromatofocusing Aspects}

Chromatofocusing is the only chromatographic technique that separates proteins using a linear $\mathrm{pH}$ gradient. One recent chromatofocusing technique performed an initial off-line fractionation of proteins by collecting 0.2 to $0.3 \mathrm{pH}$ range fractions and then subjecting these fractions to a reversed-phase-LC-MS analysis [6-8]. In contrast, the gCF-MS technique reported here was completely on-line, maintaining the high-resolution chromatofocusing separation through its direct interfacing to the mass spectrometer via ESI. The improved resolution of gradient chromatofocusing compared with the commonly used salt gradient ion-exchange HPLC arises from its enhanced focusing capabilities [26]. Use of $\mathrm{pH}$ gradient elution at relatively low buffer concentrations allows for direct analysis of proteins separated by ion-exchange HPLC by mass spectrometry.

Chromatofocusing techniques provide general pIbased separations of proteins. Table 1 shows that the order of elution, for the most part, follows the predicted pI order (the exception is carbonic anhydrase II). However, it is noted that elution does not occur at the theoretical pI. There are several reasons for this. One reason is that ion-exchange chromatography is a surfacebased technique, meaning that the adsorption of the protein on the ion exchanger occurs through a particular region of the protein molecule. Thus, the chromatographic behavior is not necessarily governed by an overall property of the protein, such as pI. There are also other phenomena occurring in the chromatofocusing technique that contribute to the retention mechanism, including Donnan potential [34, 35], hydrophobic interaction [36], and buffer concentration [25, 26]. It should be noted that the buffer concentration can greatly enhance the separating capability of the technique. For example, a 3-fold or greater increase in resolution has been noted when the buffer concentration is manipulated in gradient chromatofocusing [26].

Of particular note is the discrepancy in the elution $\mathrm{pH}$ for carbonic anhydrase and enolase and their isoelectric points. This may be explained by the elution being affected by a displacement mechanism caused by the high buffer concentration of application buffer (25 $\mathrm{mM}$ each of ammonium bicarbonate and pyridine), as well as the effect of the other factors mentioned above. Also, for enolase, an alkaline pI species has been reported, which is thought to result from a dissociation of enolase [27]. This may at least partially explain enolase's high elution $\mathrm{pH}$ noted in the present work.

The choice of $\mathrm{pH}$ gradient to use will depend on the proteins determined. Theoretically, proteins will be retained on an anion-exchange column, which have pIs at least one unit lower than the $\mathrm{pH}$ of the application buffer and will be eluted at a $\mathrm{pH}$ equal to the $\mathrm{pI}$ of the protein. Thus, the presently reported gradient $(\mathrm{pH} 9.0$ to $\mathrm{pH}$ 2.6) can theoretically determine proteins in the $\mathrm{pI}$ range 2.6 to 8 . However, this theoretical chromatographic behavior is not strictly held to, as the present work demonstrates. Proteins that are not within this retention/elution $\mathrm{pH}$ range can be determined by expanding the $\mathrm{pH}$ range of the gradient. This can be done by increasing the $\mathrm{pH}$ of the application buffer through addition of the volatile buffer components with higher $\mathrm{pK}_{\mathrm{a}} \mathrm{s}$. Expansion to higher $\mathrm{pH}$ ranges will also require changing the column from a weak anion-exchange column to a strong anion exchange column, so that the anion exchange ligand will be positively charged at the higher buffer $\mathrm{pHs}$ for retention of negatively charged proteins. There are very few proteins with pIs below 2.6 [37], but if needed, the $\mathrm{pH}$ of the elution buffer can be decreased further by addition of a volatile acid having a lower $\mathrm{pK}_{\mathrm{a}}$.

\section{Conclusions}

gCF-MS has great potential for protein characterization and proteomics work. Although there have been occasional reports of the use of volatile salts in ion-exchange HPLC interfaced to MS, there have been even fewer reports, if any, of a directly interfaced ion-exchange HPLC-MS technique for proteins. The present work 
demonstrates a high-resolution ion-exchange technique directly interfaced to a mass spectrometer that can be generally applied to protein separations. It is also unique in its report of a linear $\mathrm{pH}$ gradient elution scheme being directly interfaced to mass spectrometry. The current work will allow for the development of ion-exchange HPLC-MS techniques to complement reversed-phase HPLC-MS techniques, particularly in the separation and determination of proteins and other charged molecules.

\section{Acknowledgments}

The authors acknowledge support for this work by a Faculty Research Enhancement Award from the College of Arts and Sciences at Cleveland State University.

\section{References}

1. Hille, J. M.; Freed, A. L.; Wätzig, H. Possibilities to Improve Automation, Speed and Precision of Proteome Analysis: A Comparison of Two-Dimensional Electrophoresis and Alternatives. Electrophoresis 2001, 22, 4035-4052

2. Haynes, P. A.; Yates, J. R. III. Proteome Profiling-Pitfalls and Progress. Yeast 2000, 17, 81-87.

3. Opiteck, G. J.; Lewis, K. C.; Jorgenson, J. W.; Anderegg, R. J. Comprehensive On-Line LC/LC/MS of Proteins. Anal. Chem. 1997, 69, 15181524.

4. Link, A. J.; Eng, J.; Schieltz, D. M.; Carmack, E.; Mize, G. J.; Morris, D. R.; Garvik, B. M.; Yates, J. R. III. Direct Analysis of Protein Complexes Using Mass Spectrometry. Nat. Biotechnol. 1999, 17, 676-682.

5. Wolters, D. A.; Washburn, M. P.; Yates, J. R. III. An Automated Multidimensional Protein Identification Technology for Shotgun Proteomics. Anal. Chem. 2001, 73, 5683-5690.

6. Zheng, S.; Schneider, K. A.; Barder, T. J.; Lubman, D. M. TwoDimensional Liquid Chromatography Protein Expression Mapping for Differential Proteomic Analysis of Normal and O157:H7 Escherichia coli. Biotechniques 2003, 35, 1202-1212.

7. Kreunin, P.; Urquidi, V.; Lubman, D. M.; Goodison, S. Identification of Metastasis-Associated Proteins in a Human Tumor Metastasis Model Using the Mass-Mapping Technique. Proteomics 2004, 4, 2754-2765.

8. Nagalla S. R.; Canick, J. A.; Jacob, T.; Schneider, K. A.; Reddy, A. P.; Thomas, A.; Dasari, S.; Lu, X.; Lapidus, J. A.; Lambert-Messerlian, G. M.; Gravett, M. G.; Roberts, C. T. Jr.; Luthy, D.; Malone, F. D.; D’Alton, M. E. Proteomic Analysis of Maternal Serum in Down Syndrome: Identification of Novel Protein Biomarkers. J. Proteome Res. 2007, 6, 1245-1257.

9. Jensen, P. K.; Pasa-Tolic, L.; Anderson, G. A.; Horner, J. A.; Lipton, M. S.; Bruce, J. E.; Smith, R. D. Probing Proteomes Using Capillary Isoelectric Focusing-Electrospray Ionization Fourier Transform Ion Cyclotron Resonance Mass Spectrometry. Anal. Chem. 1999, 71, 2076-2084.

10. Jensen, P. K.; Pasa-TolIc, L.; Peden, K. K.; Martinovic, S.; Lipton, M. S. Anderson, G. A.; Tolic, N.; Wong, K.-K.; Smith, R. D. Mass Spectrometric Detection for Capillary Isoelectric Focusing Separations of Complex Protein Mixtures. Electrophoresis 2000, 21, 1372-1380.

11. Tang, Q.; Harrata, A. K.; Lee, C. S. Capillary Isoelectric FocusingElectrospray Mass Spectrometry for Protein Analysis. Anal. Chem. 1995, $67,3515-3519$

12. Simpson, D. C.; Smith, R. D. Combining Capillary Electrophoresis with Mass Spectrometry for Applications in Proteomics. Electrophoresis 2005, 26, 1291-1305

13. Graf, M.; Wätzig, H. Capillary Isoelectric Focusing-Reproducibility and Protein Adsorption. Electrophoresis 2004, 25, 2959-2964.

14. Righetti, P. G. Determination of the Isoelectric Point of Proteins by Capillary Isoelectric Focusing J. Chromatogr. A 2004, 1037, 491-499.

15. Strege, M. A.; Stevenson, S.; Lawrence, S. M. Mixed-Mode Anion-Cation Exchange/Hydrophilic Interaction Liquid Chromatography-Electrospray
Mass Spectrometry as an Alternative to Reversed Phase for Small Molecule Drug Discovery. Anal. Chem. 2000, 72, 4629-4633.

16. Anacardio, R.; Cantalini, M. G.; De Angelis, F.; Gentile, M. Quantification of S-Carboxymethyl-(R)-Cysteine in Human Plasma by HighPerformance Ion-Exchange Liquid Chromatography/Atmospheric Pressure Ionization Mass Spectrometry. J. Mass Spectrom. 1997, 32, 388-394.

17. Careri, M.; Elviri, L.; Mangia, A.; Zagnoni, I. Rapid Method for Determination of Chlormequat Residues in Tomato Products by IonExchange Liquid Chromatography/Electrospray Tandem Mass Spectrometry. Rapid Commun. Mass Spectrom. 2002, 16, 1821-1826.

18. Shi, G.; Wu, J.; Li, Y.; Geleziunas, R.; Gallagher, K.; Emm, T. Olah, T. Unger, S. Novel Direct Detection Method for Quantitative Determination of Intracellular Nucleoside Triphosphates Using Weak Anion Exchange Liquid Chromatography/Tandem Mass Spectrometry. Rapid Commun. Mass Spectrom. 2002, 16, 1092-1099.

19. Le Bihan, T.; Duewel, H. S.; Figeys, D. On-Line Strong Cation Exchange Micro-HPLC-ESI-MS/MS for Protein Identification and Process Optimization. J. Am. Soc. Mass Spectrom. 2003, 14, 719-727.

20. Aguilar, M. I.; Hodder, A. N.; Hearn, M. T. W. High-Performance Ion-Exchange Chromatography of Proteins. In HPLC of Proteins Peptides and Polynucleotides, Hearn, M. T. W., Ed.; VCH: New York, 1991; p. 199.

21. Walton, H. F. Ion-Exchange Chromatography. In Chromatography, 5th ed., Fundamentals and Applications of Chromatography and Related Differential Migration Methods, Part A: Fundamentals and Techniques, Journal of Chromatography Library, Volume 51A. Heftmann, E., Ed.; Elsevier: Amsterdam, 1992, p. A227.

22. Kopaciewicz, W.; Rounds, M. A.; Fausnaugh, J.; Regnier, F. E. Retention Model for High-Performance Ion-Exchange Chromatography. J. Chromatogr. 1983, 266, 3-21.

23. Liu, Y.; Anderson, D. J. Gradient Chromatofocusing High-Performance Liquid Chromatography. I. Practical Aspects. J. Chromatogr. A 1997, 762, 207-217.

24. Liu, Y.; Anderson, D. J. Gradient Chromatofocusing High-Performance Liquid Chromatography. II. Theoretical Aspects. J. Chromatogr. A 1997 762, 47-54.

25. Shan, L.; Anderson, D. J. Effect of Buffer Concentration on Gradient Chromatofocusing Performance Separating Proteins on a HighPerformance DEAE Column. J. Chromatogr. A 2001, 909, 191-205.

26. Shan, L.; Anderson, D. J. Gradient Chromatofocusing. Versatile pH Gradient Separation of Proteins in Ion-Exchange HPLC: Characterization Studies. Anal. Chem. 2002, 74, 5641-5649.

27. Porcelli, L. J. Jr.; Small, E. D.; Brewer, J. M. Origin of Multiple Species of Yeast Enolase A on Isoelectric Focusing. Biochem. Biophys. Res. Commun $1978,82,316-321$.

28. Fredriksson, S. Scanning Isoelectric Focusing in Small Density Gradient Columns. II. Microfractionation of Column Contents. Evaluation of $\mathrm{pH}$ Course. Isoelectric Points of $\beta$-Lactoglobulins A and B. Anal. Biochem. 1972, 50, 575-585

29. Wenisch, E.; Schneider, P.; Hansen, S. A.; Rezzonico, R.; Righetti, P. G. Isoelectric Focusing in a Multicompartment Electrolyzer with Zwitterionic Membranes, Exemplified by Purification of Glucoamylase. J. Biochem. Biophys. Methods 1993, 27, 199-213.

30. Stoffer, B.; Frandsen, T. P.; Busk, P. K.; Schneider, P.; Svendsen, I.; Svensson, B. Production, Purification and Characterization of the Catalytic Domain of Glucoamylase from Aspergillus niger. Biochem. J. 1993, 292, 197-202.

31. Kebarle, P. A Brief Overview of the Present Status of the Mechanisms Involved in Electrospray Mass Spectrometry. J. Mass Spectrom. 2000, 35 , $804-817$.

32. Cech, N. B.; Enke, C. G. Practical Implications of Some Recent Studies in Electrospray Ionization Fundamentals. Mass Spectrom. Rev. 2001, 20 362-387.

33. Dell, A.; Morris, H. R. Glycoprotein Structure Determination by Mass Spectrometry. Science 2001, 291, 2351-2356.

34. Sluyterman, L. A. AE; Elgersma, O. Chromatofocusing: Isoelectric Focusing on Ion-Exchange Columns. I. General Principles. J. Chromatogr. 1978, 150, 17-30.

35. Sluyterman, L. A. AE; Wijdenes, J. Chromatofocusing: Isoelectric Focusing on Ion-Exchange Columns. II. Experimental Verification. J. Chromatogr. 1978, 150, 31-44.

36. Melander, W. R.; El Rassi, Z.; Horvath, C. Interplay of Hydrophobic and Electrostatic Interactions in Biopolymer Chromatography. Effect of Salts on the Retention of Proteins. J. Chromatogr. 1989, 469, 3-27.

37. Malamud, D.; Drysdale, J. W. Isoelectric Points of Proteins: A Table. Anal. Biochem. 1978, 86, 620-647. 